\title{
Mechanism of Inactivation of Oral Cancer Cells Imadiated by Active Oxygen Species from DBD Plasma
}

\author{
Keisuke Mine, ${ }^{\mathrm{a}, *}$ Yukie Miyamaru, ${ }^{\mathrm{a}}$ Nobuya Hayashi, ${ }^{a}$ Reona Aijima, ${ }^{\mathrm{b}}$ \\ \& Yoshio Yamashitab \\ anterdisciplinary Graduate School of Engineering Sciences, Kyushu University, Kasuga, Fukuoka \\ 816-8580, Japan; ' Faculty of Medicine, Saga University, Saga 849-8501, Japan \\ *Address all correspondence to: Keisuke Mine, Interdisciplinary Graduate School of Engineering Sciences, Kyushu \\ University, 6-1 Kasuga-koen, Kasuga, Fukuoka 816-8580, Japan, E-mail: mine.keisuke@aees.kyushu-u.ac.jp
}

\begin{abstract}
Inactivation effect of active oxygen species generated by torch-type dielectric barrier discharge on oral cancer cells was investigated. In order to irradiate cells directly with active oxygen species, the culture medium is removed from a culture dish. Activation of c-jun $\mathrm{N}$-terminal kinase (JNK), p38 proteins, and p53 enzymes in oral cancer cells by active oxygen species indicated that the cells suffered apoptosis. Selective inactivation between cancer and normal cells was obtained by irradiation with active oxygen species for a relatively short period of less than $60 \mathrm{sec}$.
\end{abstract}

KEY WORDS: plasma, active oxygen species, oral cancer cell, selective inactivation effect, inactivation mechanism

\section{INTRODUCTION}

Recently, inactivation of cancer cells using discharge plasmas has been a fruitful theme in plasma research ${ }^{1-10}$ and elucidation of the inactivation mechanism has been investigated intensively. Studies using plasma-activated medium or plasma-activated water ${ }^{11-13}$ have shown significant inactivation effects on cancer cells. The use of plasmas is a potentially new method of cancer therapy, with fewer side effects than treatments using medicines, operations, and radiant rays. However, there have been few studies devoted to the use of plasmas in the treatment of oral cancer.

Because oral cancer cells appear on inner surface of oral mucosa, active species in plasmas are able to irradiate cancer cells directly without passing through a liquid layer. In addition, the energies of active species accelerated by an electric field remain higher than those of active species in liquids. Therefore, direct irradiation is expected to obtain larger and more varied effects on oral cancer cells than when using active species generated in liquids.

Major factors causing cancer cell inactivation in liquids have been determined to be reactive oxygen species (ROS) and reactive nitrogen species (RNS). Recent studies have clarified that apoptosis is a major mechanism of cell inactivation when cells are irradiated by plasmas. ${ }^{14-20}$ Phosphorylation of enzymes such as mitogen-activated protein kinases (MAPKs) and p53 are triggers of cell inactivation. However, the major factor 
in plasmas triggering such phosphorylation has not been identified. Phosphorylation enzymes (kinases) tend to be activated strongly by active oxygen species, including those generated from NADPH oxidase. In this study, effects of active oxygen species generated by dielectric barrier discharge (DBD) on oral cancer cells were studied to elucidate the inactivation mechanism of the cells. In addition, we attempt to explain the selective inactivation of normal and cancer cells using the difference in apoptosis between these types of cells.

\section{EXPERIMENTALSETUP}

Figure 1 is a schematic diagram of the atmospheric air torch plasma source. A cylindrical ceramic tube serving as a plasma torch with a length of $130 \mathrm{~mm}$ and an inner diameter of $4 \mathrm{~mm}$ was covered with a rectangular grounded electrode. A spiral metal electrode as a cathode was set along the inner wall of the ceramic tube. The spiral metal electrode was connected to a high-voltage (4-6 kV) and high-frequency $(10 \mathrm{kHz})$ power supply to obtain a DBD. Material gases for plasma production were air and pure oxygen. The whole experimental device was enclosed in a container to replace the ambient gas with the material gas. Active species that were produced in the gas phase between the torch opening edge and the cells were determined using light emission spectroscopy and chemical indicators. To determine the production of ROS and RNS in the thin liquid film of the culture medium, chemical indicators in which the culture medium liquid film adhered were irradiated by the atmospheric torch plasma using air and oxygen.

The cancer cell line used in this experiment was HSC3, which is a highly metastatic cell line in lymph nodes from human oral squamous cell carcinoma. For comparison, $\mathrm{HaCaT}$, a line of spontaneously transformed keratinocytes from histologically normal skin, was used as a normal cell line. HSC 3 and $\mathrm{HaCaT}$ were cultivated $(15,000 /$ well) in a 96-well plates for $24 \mathrm{~h}$ before the experiment, at which point the cells accounted for $\sim 60-80 \%$ of the area of the wells. Minimum essential culture medium ( $\alpha$ imu; WAKO) supplemented with 10\% heat-inactivated fetal bovine serum (Sigma-Aldrich) and 100 units $/ \mathrm{mL}$ penicillin and $100 \mu \mathrm{g} / \mathrm{mL}$ streptomycin (Sigma-Aldrich) was used as the culture medium. Because HSC3 and $\mathrm{HaCaT}$ are adherent cells, the plasma irradiates the cells directly when most portions of the $\alpha$-MEM in which the HSC3 cells are cultivated is removed before the cells are irradiated. After aspiration of culture medium from a microplate, ultrathin film of culture medium remains on the cell surface. The thickness of the culture medium film on the cell surface would be several micrometers. Therefore, when the torch plasma irradiates the cells, active species penetrated from the plasma torch reach the cells through the ultrathin liquid film on the cells. Plasma irradiation times were $0,5,10,20,40$, and $60 \mathrm{sec}$. If gas flow is strong enough to dry and kill cells, it is difficult to estimate the inactivation effect of active oxygen species. Therefore, a humidity of $70 \%$ was maintained for the material gases by a humidifier and the total flow rate of the gases was fixed at $0.6 \mathrm{~L} / \mathrm{m}$. When material gases without plasma were blown on cells for 40 or $60 \mathrm{sec}$, a decrease in live cell number was not observed. After cultivation of cells in a $\mathrm{CO}_{2}$ incubator for $24 \mathrm{~h}$, the cell number was counted using Cell 


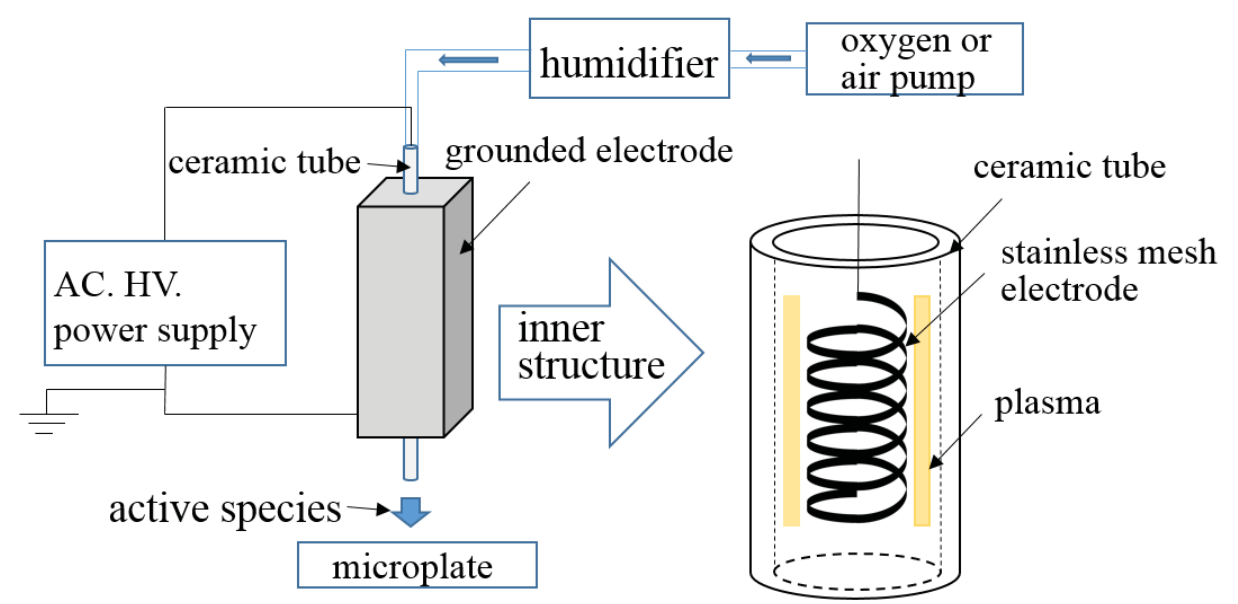

FIG. 1: Schematic diagram of the experimental apparatus and the discharge electrode

Counting Kit-8 (Dojindo).

To analyze the effect of plasma irradiation on MAPKs and p53 phosphorylation, immunoblot analysis was performed as described previously. ${ }^{21}$ Briefly, the cells were lysed in a buffer comprising $50 \mathrm{mM}$ Tris- $\mathrm{HCl}, 150 \mathrm{mM} \mathrm{NaCl}, 1 \%$ Triton X-100, 0.5\% NP-40, protease inhibitor (Nacalai Tesque), and a phosphatase inhibitor cocktail (PhosSTOP; Roche) after plasma irradiation for $30 \mathrm{~min}$ or $24 \mathrm{~h}$. Protein samples were separated by SDS-PAGE and transferred onto a PVDF membrane. The membranes were blocked with $5 \%$ bovine serum albumin for $1 \mathrm{~h}$ at room temperature, followed by incubation with anti-c-jun N-terminal kinase (JNK), anti-phospho-JNK, anti-p38, anti-phosphop38, anti-extracellular signal regulated kinases (ERKs), anti-phospho-ERK (1:4000; all from Cell Signaling Technology), phospho-p53 (1:2000; GeneTex), and anti-glyceraldehyde 3-phosphate dehydrogenase (1:1000; Santa Cruz Biotechnology) overnight at 4ht at 4chnology) overized using ECL Prime Western Blotting Detection Reagent (GE Healthcare).

\section{RESULTS AND DISC USSION}

\section{A. Active Species in Liquid Films on Cells}

Figure 2 illustrates the UV-visible light emission spectrum of oxygen plasmas generated by DBD, which was measured in the horizontal direction at $3 \mathrm{~mm}$ below the opening edge of the torch tube. A significant peak appeared at $777 \mathrm{~nm}$ and is assigned as the de-excitation process of atomic oxygen $\left[\mathrm{O}\left({ }^{5} \mathrm{~S}\right)\right]$. This atomic oxygen changes into a ground-state oxygen atom or ozone with a relatively long lifetime. Chemical indicators detecting active oxygen species showed the generation of atomic oxygen and excited oxygen molecules selectively.

Volume 7, Issue 3, 2017 


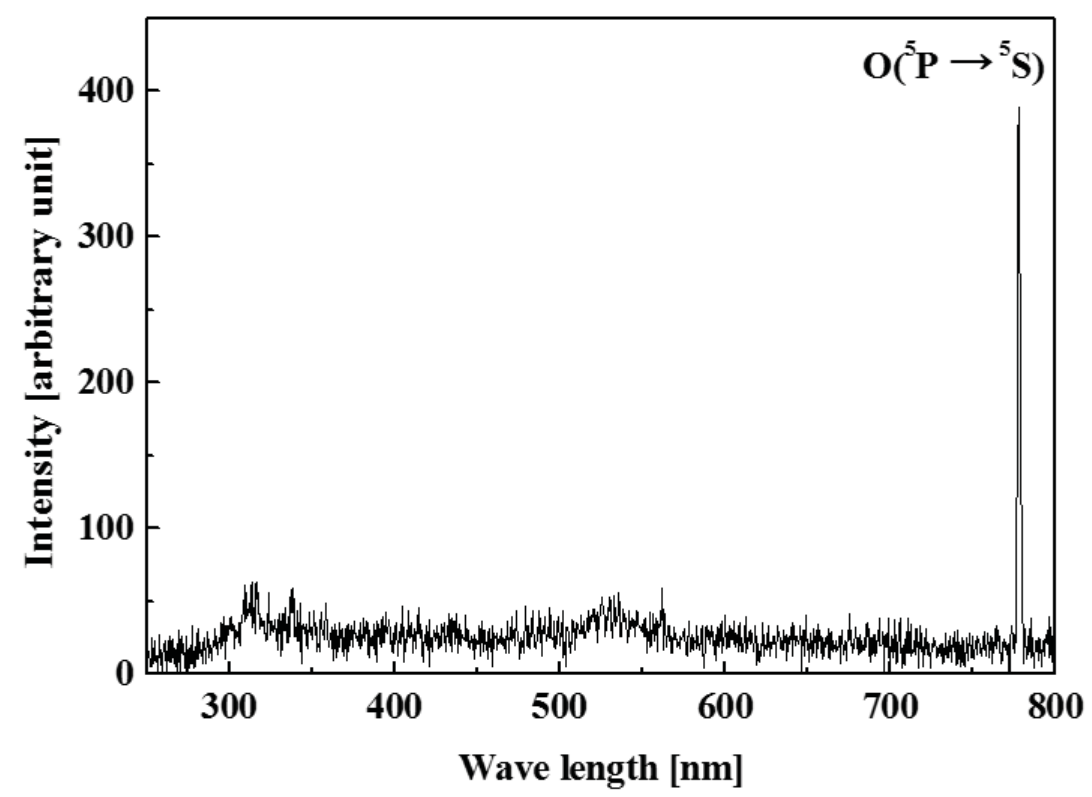

FIG. 2: UV-visible light emission spectrum of oxygen plasmas

To confirm that active species penetrated from the DBD plasma torch reached the cell surface, the chemical indicator for the gaseous active species is irradiated by the torch plasma when the surface of the chemical indicator is covered with an ultrathin liquid film of $\alpha$-MEM. After most of the $\alpha$-MEM is removed by aspiration, an ultrathin liquid film remains on the cells. Atomic oxygen and excited oxygen molecule, which are difficult to dissolve in liquids, penetrate from the plasma torch and irradiate the cell wall through the ultrathin liquid film on the cells. The color of the chemical indicator changes into green after the irradiation for several minutes. This result shows that gaseous active species can reach the surface of the cell surface through the ultrathin liquid film.

Chemical indicators for detection ROS and RNS in liquid showed production of RNS such as $\mathrm{NO}_{2}^{-}$and $\mathrm{NO}_{3}{ }^{-}$in the liquid film, as well as $\mathrm{H}_{2} \mathrm{O}_{2}$. Table 1 illustrates the amount of active species in the medium after oxygen and air plasma irradiation. $\mathrm{H}_{2} \mathrm{O}_{2}$ was generated in medium irradiated by both oxygen and air plasmas. $\mathrm{NO}_{2}^{-}$and $\mathrm{NO}_{3}^{-}$ were obtained in medium that was irradiated by air plasma. NOx species are produced by the air DBD and dissolved in the liquid film, as shown in Table 2. The above results suggest that cells covered with the ultrathin film of the culture medium are affected by both gaseous and liquid phase active species.

\section{B. Inactivation Characteristics of HSC 3 Cells}

The DBD plasmas were generated inside a torch tube and cells in the culture medium film were irradiated by active species ejected from the opening edge of the tube. To con- 
TABLE 1: Concentration of active species in culture medium $(\mathrm{mg} / \mathrm{L})$ with changes in irradiation period of oxygen plasma and air plasma

\begin{tabular}{|c|c|c|c|c|}
\hline & $10 \mathrm{~s}$ & $20 s$ & $40 \mathrm{~s}$ & $60 \mathrm{~s}$ \\
\hline \multicolumn{5}{|c|}{ Oxygen plasma } \\
\hline $\mathrm{H}_{2} \mathrm{O}_{2}$ & 2 & $2 \sim 5$ & $5 \sim 10$ & 10 \\
\hline $\mathrm{NO}_{2}^{-}$ & 0 & 0 & 0 & 0 \\
\hline $\mathrm{NO}_{3}^{-}$ & 0 & 0 & 0 & 0 \\
\hline \multicolumn{5}{|c|}{ Air plasma } \\
\hline $\mathrm{H}_{2} \mathrm{O}_{2}$ & $2 \sim 5$ & $5 \sim 10$ & $10 \sim 25$ & 25 \\
\hline $\mathrm{NO}_{2}^{-}$ & $20 \sim 40$ & $40 \sim 80$ & $>80$ & - \\
\hline $\mathrm{NO}_{3}^{-}$ & $250 \sim 500$ & $>500$ & - & - \\
\hline
\end{tabular}

firm the effect of gas flow to cells, cells were blown with both air and oxygen gas flows from the opening edge of the torch for 40 and $60 \mathrm{sec}$. The population of living HSC3 cells after gas flow treatment was almost the same as that of the untreated cells (control). Therefore, the effect of drying cells by gas flow can be ignored in this experiment and the inactivation effect of the plasma irradiation on cancer cells was therefore induced by active species in the plasma.

The dependency of cell survival on the irradiation period was significantly different between oxygen and air plasmas. Figure 3 shows the survival of HSC 3 cells irradiated by the plasmas with different irradiation periods for oxygen (Fig. 3a) and air (Fig. 3b); the irradiation period 0 indicates the untreated cells (control). In the case of the oxygen plasma, the inactivation rate was saturated and independent of the irradiation period after $40 \mathrm{sec}$. Saturation of the inactivation rate was likely due to spatial uniformity of the plasma in the microplate well. Microscopic observation of the cells indicated that the inactivation rates on the center and around the microplate well wall were significantly different. The 96-well microplates used in this study have an inner diameter of $7 \mathrm{~mm}$,

TABLE 2: Reaction formula

$\mathrm{N}_{2}+\mathrm{e} \rightarrow 2 \mathrm{~N}+\mathrm{e}$
$\mathrm{O}_{2}+\mathrm{e} \rightarrow 2 \mathrm{O}+\mathrm{e}$
$\mathrm{O}+\mathrm{H}_{2} \mathrm{O} \rightarrow 2 \mathrm{OH}$
$\mathrm{N}+\mathrm{O} \rightarrow \mathrm{NO}$
$\mathrm{N}_{2}+\mathrm{O} \rightarrow \mathrm{NO}_{2}$
$\mathrm{NO}+\mathrm{OH} \rightarrow \mathrm{HNO}_{2}$
$\mathrm{NO}_{2}+\mathrm{OH} \rightarrow \mathrm{HNO}_{3}$
$\mathrm{HNO}_{2} \rightarrow \mathrm{H}++\mathrm{NO}_{2}^{-}$
$\mathrm{HNO}_{3} \rightarrow \mathrm{H}^{+}+\mathrm{NO}_{3}^{-}$

Volume 7, Issue 3, 2017 

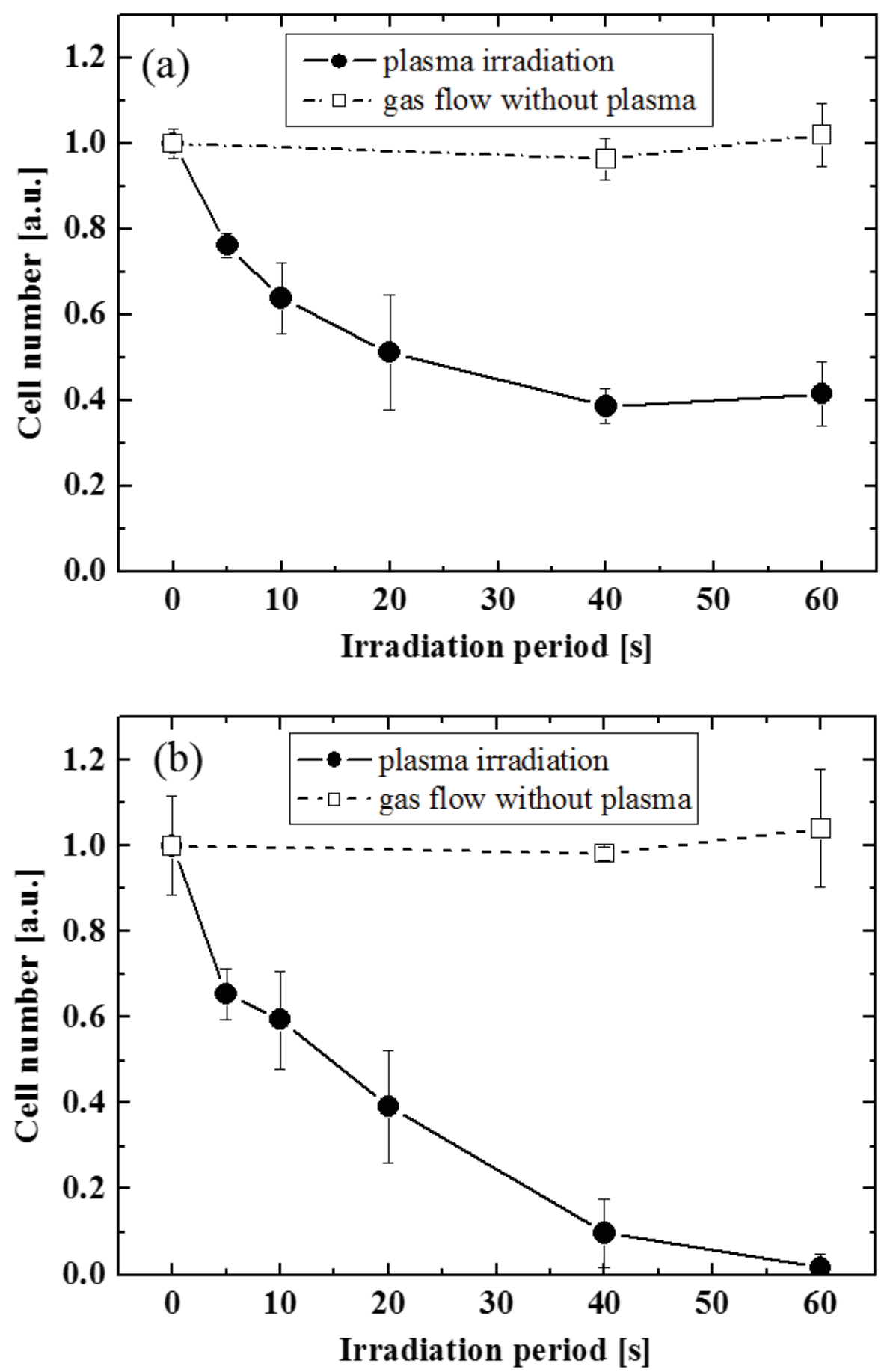

FIG. 3: Surviving numbers of HSC3 cells with changing irradiation periods of oxygen (a) and air (b) plasmas 
whereas the plasma torch tube has an inner diameter of $4 \mathrm{~mm}$. The short-lived and strong oxidizability of active oxygen species, one of the inactivation factors, did not reach the cells in the vicinity of the well wall.

In the case of the air plasma, however, the decreasing tendency depended on the irradiation period. Approximately $100 \%$ of HSC 3 cells were inactivated within $60 \mathrm{sec}$ of the irradiation period, as shown in Fig. 3. Similar to the oxygen plasma, the short-lived oxygen species were an inactivation factor. In addition, NOx with a relatively long lifespan are an inactivation factor, allowing them to reach the cells located at the outer side of the microplate well. Although the inactivation factors for oral cancer cells have not been specified, the two plasmas should have different inactivation factors. NOx in the gas phase dissolves in liquids rapidly and generates $\mathrm{NO}_{2}{ }^{-}$and $\mathrm{NO}_{3}{ }^{-}$in liquids. $\mathrm{NO}_{2}{ }^{-}$and $\mathrm{NO}_{3}^{-}$would diffuse and be distributed in the liquids uniformly and thus inactivate cells even in the vicinity of the well wall. Therefore, the inactivation effect of the air plasma is higher than that of the oxygen plasma. Although the oxygen plasma has a characteristically narrow irradiation range, its oxidization potential is enough to inactivate oral cancer cells. Because oxygen plasma does not leave harmful long-lived active species such as NOx, it is more suitable for oral cancer therapy.

\section{Selective Inactivation Effect}

$\mathrm{HaCaT}$ cells, which are in vitro spontaneously transformed keratinocytes derived from histologically normal skin, were used as normal cells to investigate the selective inactivation of cancer cells. Figure 4 shows the surviving numbers of (Fig. 4a) HSC3 cells and (Fig. 4b) $\mathrm{HaCaT}$ cells with different oxygen plasma irradiation periods and applied voltages, together with control and gas flow cases. The number of surviving oral cancer cells irradiated by oxygen plasma with a discharge voltage of $4.16 \mathrm{kV}$ decreased by approximately half of the control. Conversely, the number of normal cells did not decrease compared with controls that were not irradiated by plasmas. When plasma irradiation was applied with a higher discharge voltage of $4.56 \mathrm{kV}$, the number of surviving normal cells also decreased. These results indicate that cancer cells have a lower resistance to stimulus by oxygen plasma compared with normal cells and are inactivated selectively under optimal conditions.

The selective inactivation can be explained partly by the Warburg effect, ${ }^{22-24}$ a remarkable characteristic of cancer cells. In contrast to normal cells, which depend primarily on mitochondrial oxidative phosphorylation to generate energy, most cancer cells instead depend on aerobic glycolysis even when the oxygen supply is sufficient. Normal cells have antioxidative functions that prevent damage by active oxygen species, which are generated through oxidative phosphorylation in mitochondria. In contrast, cancer cells have little antioxidative ability because cellular active oxygens and mitochondrial oxidative phosphorylation decrease in association with the Warburg effect. ${ }^{25-28}$ The selective inactivation effect can be obtained by targeting this difference in antioxidative ability between cancer cells and normal cells with a suitable quantity of active oxygen species such as that produced by a discharge voltage of $4.16 \mathrm{kV}$, as shown in Fig. 4.

Volume 7, Issue 3, 2017 

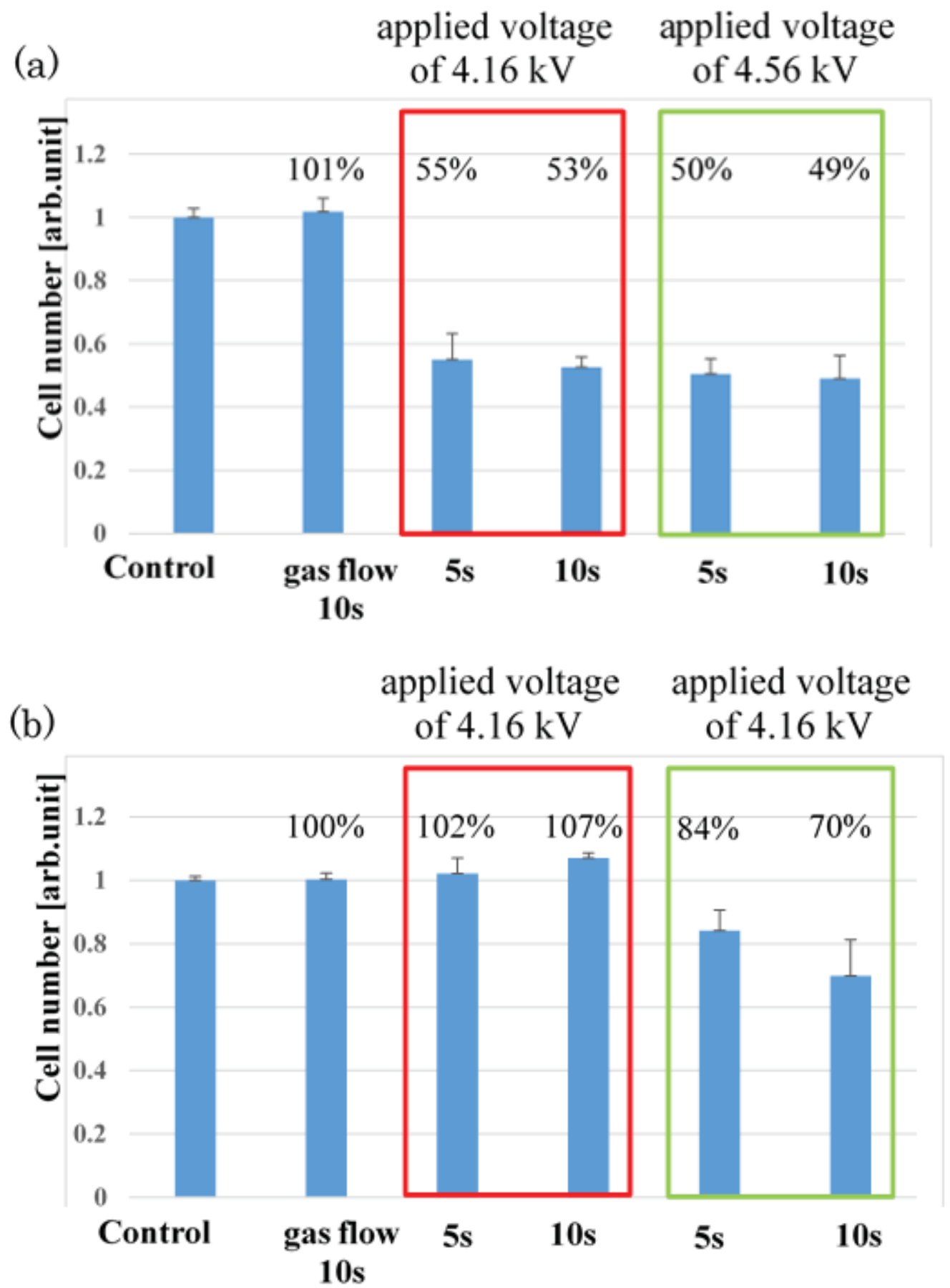

FIG. 4: Surviving numbers of $\mathrm{HSC} 3$ (a) and $\mathrm{HaCaT}$ (b) cells with changed irradiation periods and applied voltages of plasma, together with control and gas flow cases 
Plasma irradiation as demonstrated in this study may become a new treatment method for oral cancer, providing fewer side effects compared with treatments using medicines, operations, or radiant rays.

\section{MAPK and p53 are Activated by Active Oxygen Species}

To clarify the mechanism of the inactivation of cells, concentrations of various apoptosis-related proteins were measured. MAPK is a serine-threonine kinase that is activated by various stresses. MAPKs are classified into ERKs, JNK, and p38. ERK is a survival and growth signal protein in cells. JNK and p38 are apoptosis signal proteins. ${ }^{29,30}$ When cells suffer stress, the MAP kinase kinase kinase (MAPKKK) enzyme is phosphorylated. Phosphorylated MAPKKK causes downstream reactions to phosphorylate MAPKK and MAPK. Finally, phosphorylated JNK and p38 phosphorylate the apoptosis-related enzyme p53. ${ }^{31}$ Therefore, phosphorylation of the p53 protein is demonstrative of cell apoptosis. Figure 5 shows variations in the electrophoresis bands of total and phosphorylated p38, JNK, and ERK in HSC3 cells with differences in applied voltage as measured by Western blotting. HSC3 cancer cells were affected by plasmas with varying discharge voltages: (1) oxygen gas flow (control), (2) discharge voltage of $4.16 \mathrm{kV}$, and (3) discharge voltage of $5.20 \mathrm{kV}$. The irradiation period was kept at $30 \mathrm{sec}$ throughout the experiment. In this experiment, total proteins were extracted from HSC3 cells 30 min after plasma irradiation. Phosphorylated JNK and phosphorylated p38 were enhanced in relation to the discharge voltage of the oxygen plasma. In contrast, activation of phosphorylated ERK, which is a survival and growth signal, was almost the same for each plasma condition. Therefore, apoptosis of oral cancer cells can be induced by active oxygen species, but the growth of cancer cells was not affected by oxygen plasma irradiation.

The apoptosis-related protein p53 is activated by the MAPK phosphorylation sequence. To confirm the activation of p53 when HSC 3 cells were irradiated by active oxygen species, the phosphorylation of p 53 was measured by Western blotting. Figure 6 shows the electrophoresis bands of phosphorylated p53 and glyceraldehyde 3-phosphate dehydrogenase (GAPDH) of HSC3 cells, which was obtained under the following conditions: (1) oxygen gas flow (control), (2) oxygen plasma irradiation for $10 \mathrm{sec}$, and (3) oxygen plasma irradiation for $30 \mathrm{sec}$. GAPDH is expressed at high level in most tissues and the expression level is constant through experiments. For this reason, GAPDH is used as a loading control for Western blot. The applied voltage was set for $4.16 \mathrm{kV}$. In this experiment, the protein was extracted from HSC3 cells after $1 \mathrm{~h}$ (Fig. 6a) and $24 \mathrm{~h}$ (Fig. 6b) of treatment under each condition. There was no variation in the phosphorylation of p53 when the oxygen plasma irradiation period increased after $1 \mathrm{~h}$ of irradiation. Conversely, the phosphorylation of p53 was enhanced with the irradiation period of the oxygen plasma after $24 \mathrm{~h}$. This fact suggests that the response to oxidative stress of cells occurs several hours after oxygen plasma irradiation.

Volume 7, Issue 3, 2017 


\section{p-JNK \\ (46/54kD) \\ JNK \\ (46/54kD)}

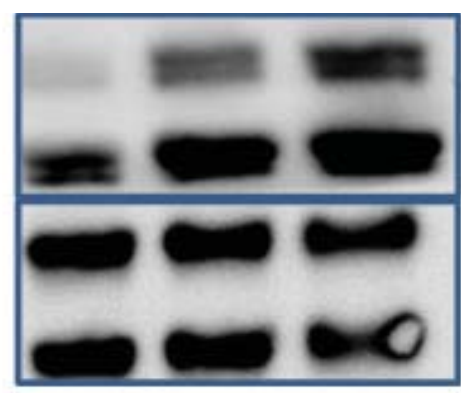

p-p38

(43kD)

p38

(43kD)
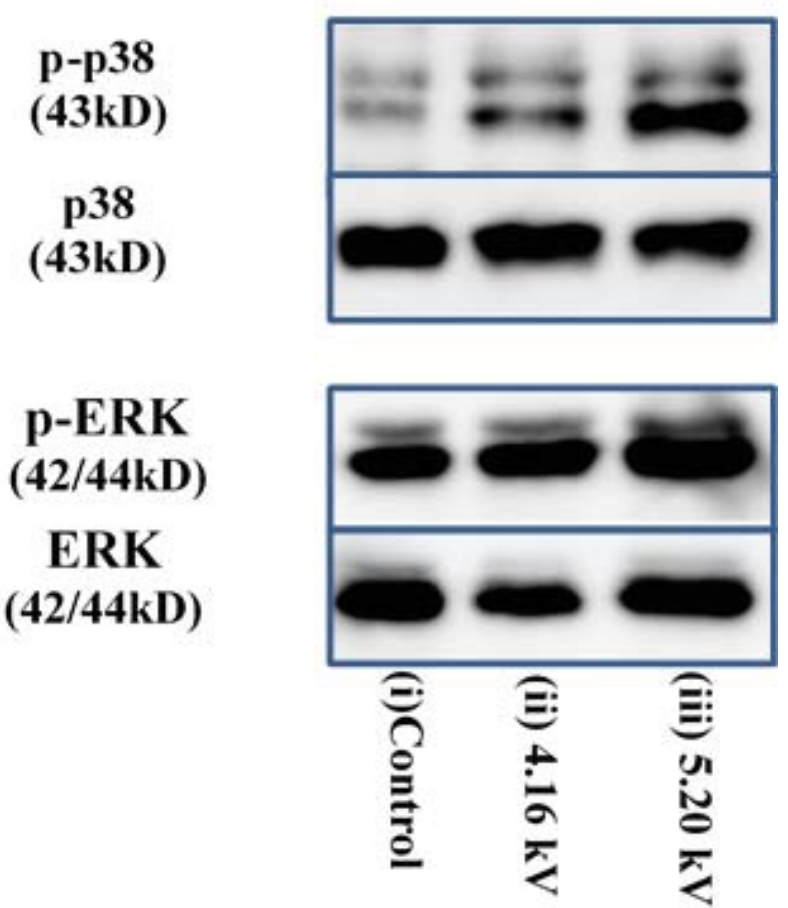

FIG. 5: Electrophoresis bands of normal and phosphorylated p38, JNK, and ERK of HSC3 cells with changing applied voltage

\section{CONCLUSION}

Total inactivation of oral cancer cells is obtained by relatively short period of $\sim 5-60 \mathrm{sec}$ when the cells are irradiated by active oxygen species after removing most of the culture medium. Selective inactivation between cancer and normal cells is obtained with the irradiation period of $10 \mathrm{sec}$. The difference in activation of apoptosis-related proteins such as JNK, p38 protein, and p53 enzymes between cancer cells and normal cells is a major mechanism in the selective inactivation. Cancer cells clearly undergo apoptosis when irradiated by oxygen plasma. 
(a)

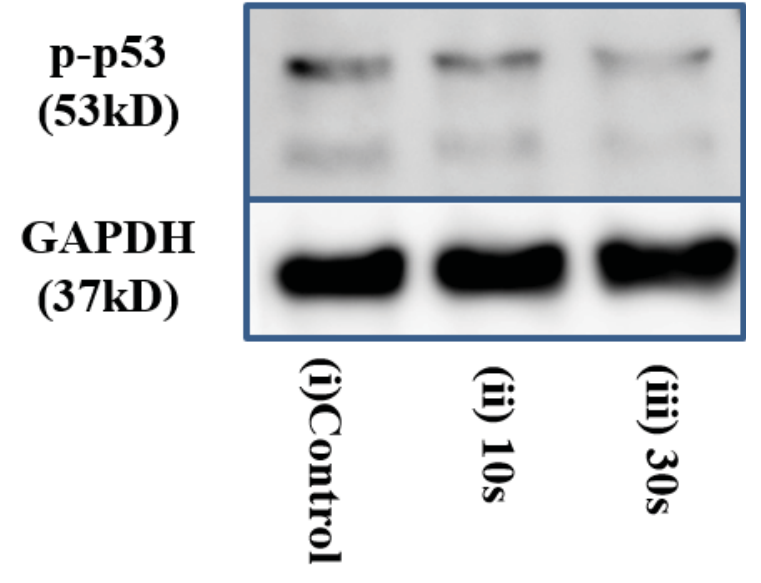

(b)

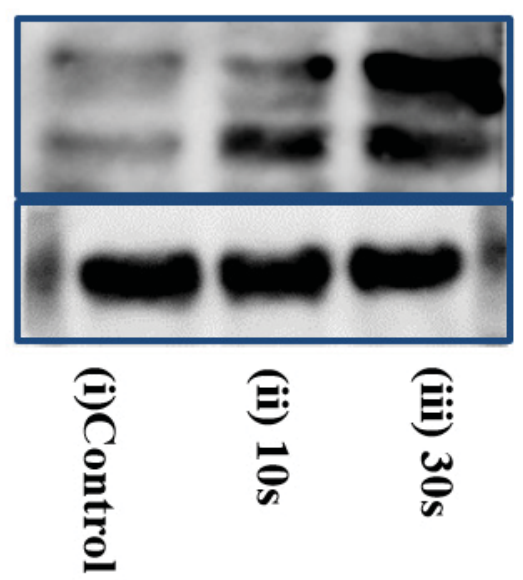

FIG. 6: Electrophoresis bands of phosphorylated p53 of HSC3 cells with changing irradiation periods of $1 \mathrm{~h}$ (a) and $24 \mathrm{~h} \mathrm{(b)} \mathrm{after} \mathrm{irradiation}$

\section{ACKNOWFDGMENT}

The authors thank Dr. Tamotsu Kiyoshima (Kyushu University) for providing the HSC3 and $\mathrm{HaCaT}$ cell lines.

\section{REFERENCES}

1. Keidar M, Walk R, Shashurin A, Srinivasan P, Sandler A, Dasgupta S, Ravi R, Guerrero-Preston R, Trink B. Cold plasma selectivity and the possibility of a paradigm shift. Br J Cancer. 2011;105(9):1295301.

2. Panngom K, Baik KY, Nam MK, Han JH, Rhim H, Choi EH. Preferential killing of human lung cancer cell lines with mitochondrial dysfunction by nonthermal dielectric barrier discharge plasma. Cell Death Dis. 2013;4:e642.

3. Volotskova O, Hawley TS, Stepp MA, Keidar M. Targeting the cancer cell cycle by cold atmospheric plasma. Sci Rep. 2012;2:636.

4. Kim GC, Kim GJ, Park SR, Jeon SM, Seo HJ, Iza F, Lee JK. Air plasma coupled with antibody-conjugated nanoparticles, a new weapon against cancer J Phys D Appl Phys 2009;42(3):032005.

5. Lee HJ, Shon CH, Kim YS, Kim S, Kim GC, Kong MG. Degradation of adhesion molecules of G361 melanoma cells by a non-thermal atmospheric pressure microplasma. New J Physics. 2009;11:115026.

6. Han X, Klas M, Liu Y, Stack MS, Ptasinska S. DNA damage in oral cancer cells induced by nitrogen atmospheric pressure plasma jets. Appl Phys Lett. 2013;102(23):233703.

7. Gweon B, Kim M, Kim DB, Kim D, Kim H, Jung H, Shin JH, and Choe W. Differential responses of human liver cancer and normal cells to atmospheric pressure plasma. Appl Phys Lett. 2011;99(6):063701.

8. Zucker SN, Zirnheld J, Bagati A, DiSanto TM, Des Soye B, Wawrzyniak JA, Etemadi K, Nikiforov M, Berezney R. Preferential induction of apoptotic cell death in melanoma cells as compared with normal keratinocytes using a non-thermal plasma torch. Cancer Biol Ther. 2012;13(13):1299-306.

9. Brullé L, Vandamme M, Riès D, Martel E, Robert E, Lerondel S, Trichet V, Richard S, Pouvesle JM, 
Le Pape A. Effects of a non thermal plasma treatment alone or in combination with gemcitabine in a MIA PaCa2-luc orthotopic pancreatic carcinoma model. PLoS One. 2012;7(12):e52653.

10. Ishaq M, Evans MM, Ostrikov KK. Effect of atmospheric gas plasmas on cancer cell signaling. Int J Cancer. 2014;134(7):1517-28.

11. Tanaka H, Mizuno M, Ishikawa K, Nakamura K, Kajiyama H, Kano H, Kikkawa F, Hori M. Plasmaactivated medium selectively kills glioblastoma brain tumor cells by down-regulating a survival signaling molecule, AKT kinase. Plasma Med. 2011;1(3-4):265-77.

12. Tanaka H, Mizuno M, Ishikawa K, Kondo H, Takeda K, Hashizume H, Nakamura K, Utsumi F, Kajiyama H, Kano H, Okazaki Y, Toyokuni S, Akiyama S, Maruyama S, Yamada S, Kodera Y, Kaneko H, Terasaki H, Hara H, Adachi T, Iida M, Yajima I, Kato M, Kikkawa F, Hori M. Plasma with high electron density and plasma-activated medium for cancer treatment. Clin Plasma Med. 2015;3(2):72-6.

13. Mohades S, Laroussi M, Sears J, Barekzi N, Razavi H. Evaluation of the effects of a plasma activated medium on cancer cells. Phys Plasmas. 2015;22(12):122001.

14. Huang J, Li H, Chen W, Lv GH, Wang XQ, Zhang GP, Ostrikov K, Wang PY, Yang SZ. Dielectric barrier discharge plasma in Ar/O2 promoting apoptosis behavior in A549 cancer cells. Appl Phys Lett. 2011;99(25):253701.

15. Kim SJ, Chung TH, Bae SH, Leem SH. Induction of apoptosis in human breast cancer cells by a pulsed atmospheric pressure plasma jet. Appl Phys Lett. 2010;97(2):023702.

16. Fridman G, Shereshevsky A, Jost MM, Brooks AD, Fridman A, Gutsol A, Vasilets V, Friedman G. Floating electrode dielectric barrier discharge plasma. Plasma Chem Plasma Process. 2007;27(2):16376.

17. Ahn HJ, Kim KI, Hoan NN, Kim CH, Moon E, Choi KS, Yang SS, Lee JS. Targeting cancer cells with reactive oxygen and nitrogen species generated by atmospheric-pressure air plasma. PLoS One. 2014;9(1):e86173.

18. Kim GJ, Kim W, Kim KT, Lee JK. DNA damage and mitochondria dysfunction in cell apoptosis induced by nonthermal. Appl Phys Lett. 2010;96(2):021502.

19. Vandamme M, Robert E, Lerondel S, Sarron V, Ries D, Dozias S, Sobilo J, Gosset D, Kieda C, Legrain B, Pouvesle JM, Le Pape A. ROS implication in a new antitumor strategy based on non-thermal plasma. Int J Cancer. 2012;130(9):2185-94.

20. Partecke LI, Evert K, Haugk J, Doering F, Normann L, Diedrich S, Weiss FU, Evert M, Huebner NO, Guenther C, Heidecke CD, Kramer A, Bussiahn R, Weltmann KD, Pati O, Bender C, von Bernstorff W. Tissue tolerable plasma (TTP) induces apoptosis in pancreatic cancer cells in vitro and in vivo. BMC Cancer. 2012;12:473.

21. Aijima R, Wang B, Takao T, Mihara H, Kashio M, Ohsaki Y, Zhang JQ, Mizuno A, Suzuki M, Yamashita Y, Masuko S, Goto M, Tominaga M, Kido MA. The thermosensitive TRPV3 channel contributes to rapid wound healing in oral epithelia. FASEB J. 2015;29(1):182-92.

22. Vander Heiden MG, Cantley LC, Thompson CB. Understanding the Warburg effect: the metabolic requirements of cell proliferation. Science. 2009;324(5930):1029-33.

23. Pavlides S, Whitaker-Menezes D, Castello-Cros R, Flomenberg N, Witkiewicz AK, Frank PG, Casimiro MC, Wang C, Fortina P, Addya S, Pestell RG, Martinez-Outschoorn UE, Sotgia F, Lisanti MP. The reverse Warburg effect: aerobic glycolysis in cancer associated fibroblasts and the tumor stroma. Cell Cycle. 2009;8(23):3984-4001.

24. Feron O. Pyruvate into lactate and back: from the Warburg effect to symbiotic energy fuel exchange in cancer cells. Radiother Oncol. 2009;92(3):329-33.

25. Jones RG, Thompson CB. Tumor suppressors and cell metabolism: a recipe for cancer growth. Genes Dev. 2009;23(5):537-48.

26. Oberley TD, Oberley LW. Antioxidant enzyme levels in cancer. Histol Histopathol. 1997;12(2):52535.

27. Huo W, Li ZM, Pan XY, Bao YM, An LJ. Antioxidant enzyme levels in pathogenesis of oral squamous cell carcinoma (OSCC). Drug Res. 2014;64(11):629-32. 
28. Le A, Cooper CR, Gouw AM, Dinavahi R, Maitra A, Deck LM, Royer RE, Vander Jagt DL, Semenza GL, Dang CV. Inhibition of lactate dehydrogenase A induces oxidative stress and inhibits tumor progression. Proc Natl Acad Sci U S A. 2010;107(5):2037-42.

29. Johnson GL, Lapadat R. Mitogen-activated protein kinase pathways mediumted by ERK, JNK, and p38 protein kinases. Science. 2002;298(5600):1911-2.

30. Zhu X, Castellani RJ, Takeda A, Nunomura A, Atwood CS, Perry G, Smith MA. Differential activation of neuronal ERK, JNK/SAPK and p38 in Alzheimer disease: the 'two hit' hypothesis. Mech Ageing Dev. 2001;123(1):39-46.

31. $\mathrm{Xu} \mathrm{Y}$. Induction of genetic instability by gain-of-function p53 cancer mutants. Oncogene. 2008;27(25):3501-7.

Volume 7, Issue 3, 2017 
